\title{
Kinds of Physical Subtraction in Islamic Jurisprudence and Iranian
}

\section{Law}

\author{
Ali Khalaphi ${ }^{1}$, Mohammad Roshan ${ }^{2}$ \& Ebrahim Taghizadeh ${ }^{1}$ \\ ${ }^{1}$ Payame Noor University, Iran \\ ${ }^{2}$ Shahid Beheshti University, Iran \\ Correspondence: Ali Khalaphi, ayame Noor University, Iran. E-mail: mamhs14@yahoo.com \\ Received: February 14, 2016 Accepted: March 8, 2016 Online Published: March 31, 2016 \\ doi:10.5539/jpl.v9n2p163 URL: http://dx.doi.org/10.5539/jpl.v9n2p163
}

\begin{abstract}
It must be said that the family foundation is based on agreement, dedication, recognition of others rights and to respect them, observing the principle of sacrifice and patience in adversity. If a couple could not compromise with each other, regardless of its reason, this important foundation will be decomposed and agreement in family will strengthen the power of family. By provocation of differences, family will lose its function and disagreements will show up that may lead to divorce. In Iran legal system, the only foundation that can be said has similarities with physical separation, is the foundation of 'Uddah' after revocable divorce. In the period of said 'Uddah', the couple has some responsibilities of marriage, but there is no force of coexistence and coition. Special docility with meaning of responding to sexual needs of couple is not among the joint task.
\end{abstract}

Keywords: court order, Physical subtraction, Number, Mental divorce, Custody and alimony, Recobely Divorce

\section{Introduction}

What is important in this paper is the unique position of family foundation and in all of legal entities formation, existence and termination of it is considered. Because of this feature the foundation of family in the level of shaping is similar with other contracts but in the level of termination has various differences.

Our legal system has categorized this issue. Before divorce anticipated the certification of the impossibility of compromise and maybe from the time of certification issuance of impossibility of compromise to the expiry date of it, divorce shall not happen. Because of that, the certification of compromise impossibility is for creation of new opportunity for the couple to revise their decision.

Of course there are some objections, but the origin is confirmed. Now the question is "whether when man refers to issuance of compromise impossibility, it is the verdict of court and the parties shall refer to scriptorium for divorce or there is a procedure to guide them to advisor and let them think more about divorce?" although all of judges has the rate of jurist, but in compensation of scientific disputes with jurists always there is a specific feature. The judge limited with implementation of the law and shall not go further in practice. The dissolution is sometimes with the will of man and sometimes out of his will. Recently law makers in family support act tried to regulate it in shape.

In France legal system, except for physical separation which is not in our law, there are three shapes: sometimes man asks for divorce, sometimes woman and sometimes both. The compromise impossibility made by our law and has not rooted in religious jurisprudence. Law maker made the certification regarding to the nature that certification has, there shall be various effects. In some courts the certification shall be issued just to refer couple to scriptorium for divorce. But in some verdicts the certification name, named in the text. As an example after the writing of compromise impossibility in the verdict while they don't divorced yet, court in its verdict refers to dowry and alimony.

Although Iran is not familiar with physical separation but functional and custom examples of law is obvious. The paper tries to prevent from immediate and emotional decisions by providing legal solutions in order to regulate the financial and non-financial relation of discordant couples.

It must be added that the paper will survey the examples of physical separation in two seasons: First season: investment of 'Uddah' and existence of fear and physical loss in physical separation. Second season: investment 
of lien and disobedience in physical separation.

\section{General Definitions}

\section{A) Divorce}

\section{- Literal definition}

Divorce in literal definition means separation of woman from man, to be released from marriage, release of woman from marriage.

\section{- Judicial definition}

Divorce in religious term means: removing indicating marriage without response with divorce and similars. Firstly divorce is among unilateral obligations that defined the "Javaherolkalam" book and is not among contracts and just exigency is sufficient for it but if it would be among legal contracts, admission is needed in addition to exigency, which in this case it will be a two way contract while the divorce itself is one-sided and happened by man. Secondly, divorce is not termination rather on the base of special concubine like divorced happens while if it was termination it did not need special concubine. Thirdly, in definition writes the nature of divorce is responsless and it means a divorce that have response is not in the definition of divorce.

\section{- $\quad$ Legal definition}

Divorce in law means dissolution of marriage with observance of special procedure. In fact divorce means legal termination of marriage and separation of couples from each other and after that mutual tasks and responsibilities will be terminated. Usually divorce happens when the strength of marriage relation dissolves; there are tensions and incompatibility between them.

Social divorce is to change in friendship, and other social relations that the divorced man or woman concern about them. Psychological divorce is the position in which a person cut its emotional dependence from the spouse and chooses to live alone. There is difference between divorce and termination of marriage. Termination of marriage means that: the marriage is null and void from the beginning of it. Ways of divorce in law of various countries are too different but in most countries there is a requirement of a confirmation from court or legal official references. In any religion there is a different approach toward divorce. Divorce in Islam shall be carried out by will of man but woman in special cases shall enjoy the divorce right.

\section{B) History of divorce}

Divorce was existed in most of traditional lands such as Egypt, Iran, Greece and China. 'Constantin' created so many limitations for divorce and in the tenth century the church banned it. 'Henry the $8^{\text {th }}$ ' $f$ or the first time asked from the Church of England to terminate his marriage. Gradually, European and Christian countries recognized the divorce right; However, in 1986 Ireland parliament banned divorce. In England 1969 the legal bill for divorce amendment ratified. In 1960s the rate of divorce in England exceeds 9\% yearly and during the decade doubled. Today in many of European societies, divorce rate increased. In countries which homosexual marriage is legal the divorce of them has been anticipated. In the legal system of those countries according to statistics the divorce rate among homosexuals are less than the others.

\section{C) Kinds of divorce}

\section{Revocable divorce}

Irrevocable divorce is a kind of divorce, in which the divorced man cannot refer to his ex wife. In other words, as the divorce happens, man and woman are not spouse anymore and if they want to recreate the relation, in case there would be no obstacle, new marriage is required. In revocable divorce, the divorced man shall refer to his ex wife during 'Uddah' and shall continue his marriage with her without new marriage. The divorce is called revocable divorce. Revoke shall be done whether by word or in practice and as it was told for reference new marriage is not required. Man shall not oust the woman from her residence, even if it was his residence too. During the 'Uddah' if man or woman commits adultery, the adultery is the adultery of married person. Existence of these responsibilities and rights and this situation about the woman divorced in revocable divorce to be promoted to real spouse, as if there were no divorce prior to the idea that some elites call her 'wife' and some others the 'real wife', in other words from view point of said group, revocable divorce does not burst the family foundation, and the foundation shall be continued.

\section{Irrevocable divorce}

In this kind of divorce man shall not do anything for the return of his wife and in case he asks for it, he must marry her according to legal and judicial protocols. One of the main effects of irrevocable divorce is the 
complete separation of spouses from each other and because of this divorce, man and woman will be separated completely and man shall marry without the consent of court, also he has no obligation to pay dowry to his ex wife. In this kind of divorce, man and woman shall not be inherited from each other and wife must leave the man's house. If she doesn't have 'Uddah' she shall marry immediately and use her own family and residence. She can live her life on her own. In case of disease, if man divorces his wife and dies of the disease, she shall inherit, in case man not remarried.

Disposal divorce

In this kind of divorce man is divorced and wife is divorced too. The wealth woman pay to man shall be dowry, amount equivalent to dowry, or less or more than that. Article 1146 of Iran civil code says: A 'Khul'a' divorce occurs when the wife obtains a divorce owing to dislike of her husband, against property which she cedes to the husband. The property in question may consist of the original marriage portion, or the monetary equivalent thereof, whether more or less than the marriage portion.

\section{Mubarat Divorce}

Mubarat means 'hatred from each other'. The differences of this kind with the aforementioned one, is that the hatred is bilateral, therefore, the exchange of divorce shall not be more than dowry.

D) Uddah

\section{Definition}

Uddah in word means number, crowd and group. It is rooted in Uddah from Arabic.

\section{Juridical definition}

In jurisprudence, Uddah is a period of time woman must wait to be able to remarry. To take Uddah is an allusion of 'home retreat'.

Legal definition

Uddah is a period of time woman is not allowed to marry again after the death of her husband or divorce from him. The length of period is not fixed due to the kind of marriage termination, kind of marriage, situation of woman pregnancy. The cause of Uddah is to prevent from generation mix, to respect the ex marriage relation and worship.

In case a woman marries a man in Uddah period, the marriage is void and if they are aware of the writ, their marriage will be banned forever. Also man shall refer to his wife during the revocable divorce.

Generally in revocable divorce Uddah, duties and rights of spouse remains. (e.g. man must pay the woman's dowry, in case of death they will inherit from each other and if in period of Uddah one of them have sexual relation out of marriage framework, it is the adultery of married person).

E) Kinds of Uddah

\section{Death Uddah}

Man's death Uddah is 4 month and 10 days. Some minorities believe on the half of said period. If the woman be pregnant, her Uddah is the longest one between her delivery and end of the Uddah. It means that at least 4 month and 10 days or more. Death Uddah is general whether for permanent or temporary, even the postmenopausal woman or a woman whom there was no coition with her husband. In this period ornament is banned for woman.

\section{Divorce Uddah}

Divorce Uddah in permanent marriage is passing three periods of purity and about a woman who is not menstruating and not at the age of postmenopausal is 3 month. Divorce Uddah in temporary marriage in case of not being menstruating in menstruation age is 45 days. There are 3 minor ideas about it: one purity, one and half purity and two purities. In Iran legal system, against the famous believes, the idea of two purities has been appointed. The divorce Uddah of bondwoman from the free husband is two purities. If in time of divorce woman be pregnant her Uddah contrary to aforementioned cases is by the end of her pregnancy, however she delivers minutes after divorce her Uddah terminates. Postmenopausal women, old women who has no menstruation and the immature woman, even has coition with her husband has not Uddah after the divorce.

\section{Pregnant woman Uddah}

Pregnant woman Uddah whether in permanent and temporary divorce and whether in divorce, dissolution or death of the man is up to the delivery time. Just in the case of man's death if the remaining time to delivery be less than 4 month and 10 days, woman must wait until the 4 month and 10 days passes. If the fetus aborted, 
Uddah will be terminated at the time.

Temporary marriage Uddah

In temporary marriage, pregnant woman's Uddah is up to delivery like the permanent one and the death Uddah is 4 month and 10 days. But the dissolution Uddah or granting the time is less than that of permanent one. In a woman who has no menstruation despite of not being postmenopausal is 45 days.

\section{The Postmenopausal Uddah}

The woman neither has divorce Uddah, nor marriage dissolution but she has death Uddah which at the same period of usual woman. Religious elites believe that the age of postmenopausality is at the age of 50 .

$1^{\text {st }}$ season: survey the examples of Uddah and fear of physical loss in physical separation.

$1^{\text {st }}$ discussion: revocable Uddah (first example, physical separation in Iran)

Uddah dedicated to woman and is from the consequences of marriage dissolution such as divorce, death, marriage dissolution and doubtful coition and is among obstacles of remarriage. From jurisprudence point of view, Uddah includes: the period of time a woman waits after separation from man, whatever was the cause of separation. 'Allameh Helli' believes: the period of time woman must wait and prevent remarriage after the dissolution of marriage because of her husband's death, or to be assume of her uterus purity or because of religious worship, assuming her believe of uterus purity.

'Sani' writes: Uddah from religious point of view is a defined period of time in which woman must wait to be assuring of not being pregnant. Uddah is for protection of generations and to prevent from generation mix. The Holy Quran in some verses has writ about the Uddah of woman in various situations: Divorced women shall wait by themselves for three periods of purity (Al Baqara-228). As for those of you who die leaving wives, they shall wait by themselves four months and ten days (Al Baqara-234). As for those of your wives who do not hope to have menses, should you have any doubts, their term shall be three months and for those who are pregnant; their term shall be until their deliver (Talaq-4).

Women who has not coition, do not need to keep Uddah. Uddah was not from the installation writs of Islam and it has been observed by nations before Islam. Islam assigned Uddah to Muslims for specific reasons and Uddah has its own rules and principles. The civil code of Iran in third discussion season two dedicated to Uddah. In Article 1150 of said code comes: Uddah consists of a period during which a woman whose matrimonial bond has been dissolved cannot marry. Article 1151 says: The period of Uddah for a divorce or for the dissolution of a marriage consists of three consecutive monthly periods of a woman unless the woman concerned though of child bearing age has no monthly period, in which case the period of Uddah will be three months.. In article 1152 it comes the period of Uddah for divorce or dissolution of marriage or waiver of the remaining period or its expiry in the case of temporary marriage for a non - pregnant woman is the expiry of two monthly periods unless contrary to the nature of her age, she no such periods, in which case the period will be 45 days.

In article 1150 civil code we have: Iddah consists of a period during which a woman whose matrimonial bond has been dissolved cannot marry. The article 1151 comes: The period of Iddah for a divorce or for the dissolution of a marriage consists of three consecutive monthly periods of a woman unless the woman concerned though of child bearing age has no monthly period, in which case the period of Iddah will be three months. 1152 says: The period of Iddah for divorce or dissolution of marriage or waiver of the remaining period or its expiry in the case of temporary marriage for a non - pregnant woman is the expiry of two monthly periods unless contrary to the nature of her age, she no such periods, in which case the period will be 45 days. Article 1153 goes: the period of Iddah for divorce or dissolution of marriage act or waiver or expiry of the period of marriage in the case of a woman who is pregnant will be until she given birth to a child. The $1154^{\text {th }}$ article says: The period of Iddah in the case of death (of husband) in both permanent and temporary marriages will be four months and ten days, unless the wife is pregnant when the Uddah comes to an end with the birth of the child provided that the interval between the death of the husband and the birth of the child is longer than four months and 10 days: if not, the period of Uddah will be the same four months and 10 days.

Another writ is Article 1155 - There is no Iddah in the case of a wife who has not had any matrimonial intercourse with her husband, or in the case of a wife beyond the age of conception who is not affected by any Uddah for divorce or for dissolution of marriage. But the Uddah for death must be observed in both cases. According to article 1156 The wife of a continuously absent husband whose whereabouts are unknown, if divorced by a judge, must observe Uddah for death, starting from the date on which the divorce was granted and also article 1157 says: A woman who has had matrimonial relations by way of mistake with someone must observe the Uddah laid down in cases of divorce. 
Some of the articles of Iran civil code are the same with other Islamic countries and some are different.

\section{A) Philosophy of Uddah}

All of the religious elites believe that the Uddah is among religious affairs because of being written in holy Quran. In verse 228 of AL Baqarah we have: Divorced women shall wait by themselves for three periods of purity [after menses], and it is not lawful for them to conceal what Allah has created in their wombs if they believe in Allah and the Last Day; and their husbands have a greater right to restore them during this [duration], if they desire reconcilement. The wives have rights similar to the obligations upon them, in accordance with honorable norms; and men have a degree above them, and Allah is all-mighty and all-wise.

The specification of Uddah in Quran leads to the idea that the Uddah is a worshipping act by woman and it is obligatory for her to observe it. Therefore there are two points of view toward the Uddah:

1- Uddah has specific reason and according to Quran the reason is assurance of being pure in uterus. Therefore if according to experiments it is clarified that the woman is not pregnant, no Uddah needed. The idea is at the minority

2- Uddah is all of the cases is obligatory, however some reasons of Uddah clarified but it must be observed.

b) Uddah as a worshipping act

Some religious elites believe that keeping Uddah, even if women be assuring of her uterus clarity is obligatory. 'mohadeth bohrani' in definition of Uddah says: woman shall keep Uddah to be assure of her uterus clarity or do it just as worshipping act.

The result of canonization philosophy is that the principle of keeping Uddah in divorce is obligatory, it is because of assurance from uterus clarity and being prepared to be referred by a man in revocable divorce, and with the reiteration of Quran is definite. Other said reasons have been gathered from clarifying and definitions by lawyers witch need more investigations.

c) Woman's Uddah in revocable divorce

In case of marriage dissolution, keeping Uddah is obligatory for woman to prevent from generation mix.

$2^{\text {nd }}$ discussion: fear of physical, monetary and honor loss

One of the cases in which woman shall refrain from husband's obey is while living in husbands house may have the fear of physical, monetary and honor loss. According to religious point of view man shall punish woman by observing some rules in limited manner. But if man behaves out of the rules, woman shall leave the house. Therefore in the case wife leave the house because of fear shall not be called as disobedience.

In civil code Article 1115 - If the existence of the wife and husband in the same house involves the risk of bodily or financial injury or that to the dignity of the wife, she can choose a separate dwelling: and if the alleged risk is proved the court will not order her to return to the house of the husband and, so long as she is authorized not to return to the house, her cost of maintenance will be on the charge of her husband.

The aforementioned loss may have various reasons. Maybe the fear is raised from the environmental situation or physical condition of the house. In the case also woman shall leave the house.

Some lawyers defined the fear as: fear from physical loss includes fear of woman from hurt, beat and murder which is raised from mans behavior directly or indirectly. Fear from financial loss refers to the fact that the woman signed a contract because of her fear from her husband. The fear from honor loss refers to the case woman fears that the shouts and family curses of man shall leads to scandal for woman or man invites infamous person in house. As an example in a case man asked for woman's obedience and woman referred to the case of hurt by the man, court sees the man as guilty and rejected the case raised by the man.

Deception is a ground for annulment of a contract where the schemes used by one of the parties are such that it is obvious that, without them, the other party would not have entered into the contract. It may not be presumed, and must be proved. (Civil code 1116)

The verdict of the court in assigning the temporary place of wife's living shall be until the end of trial as a temporary order, because in these fields which are relating with prestige and health of people, it is not possible to wait until the end of trial.

Living of woman in a place except for man's place in a period there is a fear of physical loss shall not be a sign of disobedience; therefore dowry is up to the man. But in case court does not decide the fear, woman must return to man's house. And if woman does not live in the residence provided by court, therefore there will be no cause 
for disobedience.

$2^{\text {nd }}$ season: survey the lien and disobedience in physical separation

Topic one: lien for woman (the third example of physical separation in Iran)

Regarding the used words in lien, it has a clear meaning which is: to provide some one the advantage of keep something and do not deliver it. The right is among the rights of people.

Lawyers do not think the same about the issue. Some believe this is an objective right and some see it as debt right. But in Islamic jurisprudence lien is an objective right and because of that in Islamic jurisprudence books lien called as an objective right. Some of lawyers, especially European ones, see the right as a debt right because no right to prosecute has been defined for it. Differences in lien sometimes refer to the attached. If the attached be object, it is called the objective right but always it is not the case.

Therefore the right attached sometimes is a person and sometimes is the contract. So lien in selling contract shall be categorized in the first group and call it as object attached but the lien in marriage belongs to a person e.g. right of nemesis and custody.

It seems that the differences among lawyers and religious elite's ideas rose from the understanding of them of the right. Eventually it can be said that the lien from one side is financial and other side non-financial, and in financial case it is objective right.

Some sees the lien as objective right regarding to French lawyers, also about the quiddity of right some believe on the personality of it and some sees it as specific objective right and some believe that the right is not personal but is a right for any debtor to stop doing commitments until he is creditor from the party.

Makaseb authors told that the lien is among mutual defense of contract parties.

In insolvency issue most of the religious elites believe that the insolvency of man does not affect lien, in other words does not exempt the right, in the issue there is an opposite idea which belongs to Ibn Idris.

Anyway the right is belongs to the woman whether he is insolvent or not. It is obvious that although insolvent shall void the claim right, woman shall disobey.

Imam Khomeini in 'Tahrir Vsileh' followed the idea as: woman shall prevent from obedience to the man until receive the entire dowry, in case the dowry be prompt.

A) Reluctance and force the woman to obedience is the cause of lien void

What is followed by writers of Iran civil code is that, if woman obey with reluctance and out of her will her lien shall not be void. According to civil code article 1086: A gift may also be made by an ante-nuptial agreement in favor of the spouses and of children to be born of their marriage, subject to the condition of paying without distinction all the debts and charges of the succession of the donor, or subject to other conditions of which the fulfillment depends upon his wish, by whatever person the gift is made: the donee is obliged to fulfill the conditions unless he prefers to renounce the gift; and in case a donor by an ante-nuptial agreement has reserved to himself the power to dispose of an article included in the gift of his existing property, or of a fixed sum to be taken out of that same property, if he dies without having disposed of them, the article or the sum shall be deemed included in the gift and shall belong to the donee or his heirs.

In "Sharaye" it is written that if woman reluctantly obey, she shall use the lien after that.

According to article 203 of Iran civil code it seems that reluctance in contract shall terminate it, even if be by the contract parties. It can be said that reluctance in obedience of woman before payment of dowry shall not terminate the lien and therefore if we accept the opposite idea, except for the case woman obey man with her will and a case obey with force what is the difference between them and from one side it can be said that termination of the right in force situation is against justice. Any way as it was told previously, the subject of civil code is not termination of woman lien and the idea received by the opposite meaning of article 1086.

In fact what has been considered in the subject is obedience in its specific meaning, which is marriage and coition that is the major idea of religious elites and lawyers. But some includes obedience as marriage that in the case discussion shall be different.

B) Man's lien and termination cases

Some of lawyers do not believe in man's lien. But some of religious elites and lawyers believe on it. One of the cases man's lien terminates is while prior to the obedience of woman, man pays the dowry and as it was told if woman obeyed before the dowry received, she herself terminates the lien. 
Another case happens when the dowry is on demand but for obedience there assigned a respite, in the case man shall pay the dowry and he cannot ask for woman's obedience, because in obedience of woman there assigned a respite therefore man shall not refer to lien.

Lawyers see the lien of man as terminated in two cases. Firstly while the man prior to woman's obedience pays the dowry and secondly, when there is a respite for woman obedience. The case is like the case which the dowry is no matured and we saw that the woman's lien terminates and assignment of respite for obedience shall lead to man's lien termination.

It must be said that in cases woman's lien terminates and religious elites believe on it and also followed by civil code are these two cases:

a) While a deadline has been assigned for the dowry payment

b) While woman obey with her will before reception of dowry

The case is the same for man. Also from one side it's good to know that the writers of civil code, observed these issues in marriage section. Anyway according to aforementioned matters it cannot be received that the lien is the relaxant of marriage contract because lien is the warrant of dowry payment and obedience of woman must not hurt the marriage philosophy.

Second issue: disobedience in civil code (fourth example of physical separation in Iran)

Obedience and disobedience is one the issues of family rights. Obedience is to carry out marriage tasks and disobedience is opposite of it. The subject deeply related to family and accepted bases shall clear the domain of issue.

Obedience and disobedience usually used for woman and its effects about woman, is the idea of religious elites and even lawyers. The issue used for woman not man.

In Iran civil code Obedience and disobedience has not been used and lawyers has deduct it from some articles of it:

Article 1108: Four requisites are essential for the validity of an agreement: The consent of the party who binds himself; His capacity to contract; a definite object which forms the subject-matter of the undertaking; a lawful cause in the obligation.

Article 1085: Where the statement mentioned in the preceding Article was not annexed to the instrument containing a gift of the existing and future property, a donee is obliged to accept or repudiate that gift in whole. In case of acceptance, he may claim only the property existing on the day of the death of the donor, and he is liable to pay all the debts and charges of the succession.

The first article implicates disobedience. Some of the lawyers used the general obedience for the first article and specific obedience for the second one. Two other articles in Iran civil code has come which define the joint tasks of man and woman:

Article 1103: It is unilateral where one or more persons are bound towards one or several others, without there being any obligation on the part of the latter.

Article 1104: It is commutative where each party binds himself to transfer or do a thing which is considered as the equivalent of what is transferred to him or of what is done for him. Where the equivalent consists in a chance of gain or of loss for each party, depending upon an uncertain event, a contract is aleatory.

a) Disobedience in religious sources

In shia religious knowledge, the discussion of obedience and disobedience, in addition to dowry are named. But disobedience called independently or with kind and discord. 'Shekh Toosi' in book 'Mabsoot' and 'Khelaf' dedicated an independent title for disobedience. Prior to him, Ibn zohreh in 'ghanieh' book dedicated a concise season to disobedience. Prior religious elites such as 'Halabi', 'Sallar' and 'Ibn Baraj' had some discussion about the issue.

After researcher 'Heli' religious jurisprudence discussions in the field became coherent and mostly obedience and disobedience discussed in dowry and disobedience.

In dowry issue, obedience has been used just in title that: if man does not pay dowry, woman is not obliged to obey. And in dowry discussion it is told that the disobedient woman shall not use the dowry right.

However, in religious jurisprudent books there is no research about obedience and its limitation which can be discussed and defended. Maybe it can be said that the first definition of obedience presented by 'Shahid Sani' 
and religious elites after him followed his ideas. Disobedience has the same situation, because usually means disobedience of woman from her man, but the area of it is not defined. This was a concise report from issue process in religious jurisprudent texts.

b) Explanation of obedience and disobedience

As it was told before there is no clarifying explanation from obedience and disobedience in religious texts. Sometimes they explained their idea by means of examples.

'Sheikh Toosi' in 'Mabsoot' told that: obedience is that the woman obeys completely. Then with an example he clarified that if woman does not obey completely is like she says: I obey you in my father's house or in a specific city, in the case she does not deserve dowry.

It must be known that obedience is not among religious texts. It means that there is no writ about the issue in any Verse or narration. But disobedience rooted in Quran in two verses.

Muslim lawyers with help of religious texts presented clearer researches. Most of them have deep relation with custom, social manners and traditions.

From effects of man headship in family is the obligation of obedience to woman. Obedience has a specific and general meaning. In specific manner it means that woman accepts usual coition with her husband and does not prevent him except in justified obstacles.

Obedience in general term means that the wife does her tasks against her husband and obey him according to law and accepts his headship in family. Therefore if man has an offbeat expectation she shall not obey.

The definition of obedience, like man's headship' is dependent to social traditions and morality. Obedience in our custom has specific and general meaning: in general, it means: to accept man's headship in family and to respect his will in upbringing of children. But specific obedience is regarding the sexual relation of man and woman. In general term the criterion man shall ask from woman is custom. In the case the degree of civility and education and age and other features of man and woman must be observed. In other words, obedience rule is the human behavior which exists in specific situation of life, and from the view point it has personal and typical field.

About the specific term of obedience, custom and moral, burden the final arbitration. The obligation of obedience has not the meaning that woman is not the matter at all. Trial about emotional and human relation is too accurate to be located in rules and origins.

Woman in marriage relation is not the producing machine. She is human and she must be behaved gently. Therefore in the arbitration the criterion for recognition is obedience, in moral and legal shape and it is both personal and typical and court must observe all of the human and custom matters.

C) Obedience and disobedience of woman, man or woman

According to religious jurisprudent books, obedience is among woman's tasks and there is no word of man's obedience. The case is the same in civil code. In disobedience the case is different and man also includes. 'Mohaghegh' in 'Sharayeh' book told: disobedience is to disobey which happens by both man and woman. The same meaning also presented by 'Javaher' owner.

As it seen disobedience of man has been told concisely and sometimes as a mere sentence. It means that they saw the general term of disobedience and then explained woman's disobedience completely.

Both man and woman have tasks and right to each other, obedience and disobedience are terms that must be discussed jointly, however one side's right is more than the other. Man and woman have tasks against each other. Man and woman both shall violate their tasks.

c) Legal effect of obedience and disobedience

For obedience and disobedience of woman there are some effects in religious jurisprudent books:

1- In case of obedience, woman deserves dowry and in case of disobedience, dowry is not obligatory to man.

2- With woman's disobedience man prevent coition with her and man shall punish woman.

And if man disobeyed, the following effects shall exist:

1- If man does not pay dowry, woman shall disobey him. Anyone who is wealthy and do not pay woman's dowry, court shall sentence him to 74 lashes.

2- If man does not observe other tasks, woman shall pursue him and she shall not do anything by herself.

Prevention of man from physical punishment and coition shall be deducted from verse 34 of Nesa surah. 
About the refusal of dowry payment by man, religious elites believe that:

She shall refuse coition before the reception of dowry, the sentence is told in some religious jurisprudence books. Whether man be wealthy or not. Some believe that woman shall refuse after the spousal night and some do not believe on it, the latter is most welcomed.

In article 1085 of civil code: So long as the marriage portion is not delivered to her, the wife can refuse to fulfill the duties which she has to her husband provided, however, that the marriage portion is payable at once. This refusal does not debar her from right of maintenance expenses.

Discussion of the issue shall be found in dowry field. About the prosecution of the issue with courts 'javaher owner' told if the disobedience of man be obvious, woman shall ask for it and she shall preach him. Woman shall not punish him or huff from her husband. Many of religious elites clarified the issue see it as obligatory, even if there will be a hope of good behaving of man after it. Physical punishment and huff need the judge order, and woman has not it.

According to article 1111: The wife can refer to the court if her husband refuses to provide for her maintenance. In such a case the court will fix the amount and will compel the husband to pay it.

The article dedicated to man's refusal from dowry payment. The question is why woman shall not huff with man and why in man's disobedience case woman must obey.

\section{Conclusion}

Physical separation is a kind of separation between spouses, without divorce and it needs the writ of court. In the case the task of dowry still exists. In the separation, the commitment of life earning terminates, but assistance remains.

Commitment to dowry payment is in opposition to dowry case regarding one of spouse's failures in tasks in divorce. But in practical separation, in addition to assistance, even the commitment to life earning exists.

As it was told previously, in physical and practical separation and Uddah of revocable divorce payment of dowry is obligatory. Article 1115 of civil code it is told that: If the existence of the wife and husband in the same house involves the risk of bodily or financial injury or that to the dignity of the wife, she can choose a separate dwelling: and if the alleged risk is proved the court will not order her to return to the house of the husband and, so long as she is authorized not to return to the house, her cost of maintenance will be on the charge of her husband.

\section{Suggestions}

1- One of the solutions of good understanding from divorce is the physical separation. It is suggested that, according to spouses situation, the judge verdict up to 6 month of separation. It means that they shall not refer to each other. We shall anticipate the separation in legal system, despite it is not legal yet but religious.

2- In the certification issue, certification means approval. Certification of the impossibility of compromise is an approval that those spouses shall not live together any more, and man has the right to refer to scriptorium and ask for divorce. The certification has not the feature. For example it has the credit of finished issue, but we only shall certify that this man and woman shall not live together anymore, not more than that. Therefore the suggestion is to make the procedures the same. Because our legal system has the problem of variation in procedures.

3- To keep spouses far from divorce, a long discussion required, therefore it is suggested that the education system must be repaired. The lawyer suggested a consultation center, consultation centers are utopias which are good for foreigners to see and appreciate.

\section{References}

Adl, M. (1385). Civil Code: Amir kabir.

Amid, H. (1387). Persian Dictionary. Tehran: Amir KABIR.

Ansari, M. (1412). Almakasseb: Al albeit.

Arad, A. (1341). Dowry, history, concept and its writs. Tehran: Mostafavi.

Bahrani, Y. (1408). Alhadaegh Alnazereh (Vol. 24-25). Qom: Nashr Eslami.

Golpayegani, M. (1372). Majma Almasael (Vol. 1). qom: Darol quran.

Hayati, A. (1393). Family Law. Tehran: Mizan. 
Heli, H. (1324). Mokhtalef Alshi e Fi Ahkam SHri e. Tehran.

Hossein Safaee, A. E. (1392). Concise Family Law. Tehran: Mizan.

Jebeee, Z. (1413). Masalek Alafham Fi Sharh Sharaye (Vol. 1). Qom: Basirati.

Kashani, A. Y. (1391). Family law (Vol. 1). qom: Allame behbahani.

Katoozian, N. (1389). Civil Code oa Family (Vol. 1). Tehran: Mizan.

Khomeini, R. (1401). Tahrir vasileh (Vol. 2). Lebanon: ALtab o sales.

Khuee, A. Tozihol Masael.

Mohagheghdamad, M. (1387). Family law, Marriage and divorce. Tehran: Center for science publication.

Mohammad Ali, A. (1377). Alnekah. Tehran: Noor Negar.

Morvarid, A. (1413). Yanabi o Alfaghihiey. Beirut: Shiite institute.

Najafi, M. (1981). Javaherol kalam. Beirut.

Qanbari, M. (1372). Legal Articles. Tehran: Ganj danesh.

Roshan, M. (1393). Family Law. Tehran: Jangal.

Safaee, H. (1391). Places and Properties (Vol. 1). Tehran: Mizan.

Seyyed Hasan, E. (1390). Civil Code (Vol. 4). Tehran: Eslamiyeh.

Sistani, A. Tozihol Masael.

Tabrizi, M. Tozih Almasael: Bargozideh.

Toosi, M. H. (1383). ALmabsoot. Qom: Islamic Publications.

Vahidkhorasani, H. (1391). Toziholmasael: Parsbook.

\section{Copyrights}

Copyright for this article is retained by the author(s), with first publication rights granted to the journal.

This is an open-access article distributed under the terms and conditions of the Creative Commons Attribution license (http://creativecommons.org/licenses/by/3.0/). 